\author{
- HOFSTEDE KULTURÁLIS DIMENZIÓINAK \\ TÜKRÉBEN
}

A munkavállalók motiválására számos alternatíva létezik. Multinacionális társaságok gyakran szembesülnek azzal a ténnyel, hogy míg egy adott motiváló eszköz egy országban meghatározó ösztönzố erố a vezetók kezében, addig ugyanaz a motivátor egy másik országban nemhogy ösztönzi, hanem inkább csökkenti dolgozói teljesítményét. Ennek az eltérésnek a hátterében gyakran kulturális különbségek állnak. Igaz ez az európai vállalati kultúráktól jelentôsen eltérô kínai vállalati kultúrára, az azt meghatározó emberi erốforrásokra, valamint azok motiválására is. A szerzô az alábbiakban a kínai kulturális sajátosságokból adódó korlátokat és lehetôségeket mutatja be úgy, hogy az egyik legtöbbet idézett interkulturális vizsgálatokat végzố holland társadalomtudóst, Hofstedet hívja segítségül. A hofstedei dimenziók lencséjén keresztül ad egy átfogó képet a kínai munkavállalókról és kulturális sajátosságaikról, valamint több, a témában jártas szerzố kapcsolódó kutatási eredményét is integrálja.

Kulcsszavak: Kína, Hofstede, kulturális sajátosságok, motiváció, munkaeró, vezetés

Kína ma a világ egyik meghatározó gazdasági nagyhatalma, mely több hazai szerzố szerint is vezetố pozícióra tör: „A nemzetközi prognózisok szerint a Kínai Népköztársaság 2020 és 2030 között át fogja venni a vezetố gazdasági szerepet a világban." (Szretykó, 2013: 5. old). „A legnagyobb tartós növekedési ütemeket Kína és India esetében látjuk." (Boda - Virág, 2010: 1089. old.) „Kína a közeljövő nagy szuperhatalma, amely a kollektív, nemzeti elkötelezettséget és a meggazdagodást túzte ki célul." (Poór, 2009: 83. old.) Ezen elôrejelzéseket megerôsíti az ország elmúlt években mért gazdasági teljesítménye (lásd 1 . ábra).

A globalizált világ kínai ,jelei” megjelentek Magyarországon is. A kínai--magyar gazdasági kapcsolatokról elmondható, hogy a Kínába irányuló hazai export a korábbi évekhez hasonlóan két számjegyú ütemben nôtt, s 2012-ben meghaladta az 1,4 milliárd eurót. A magyar termékek versenyképességét jelzi, hogy ezt

Kína GDP-változásának üteme (\%)

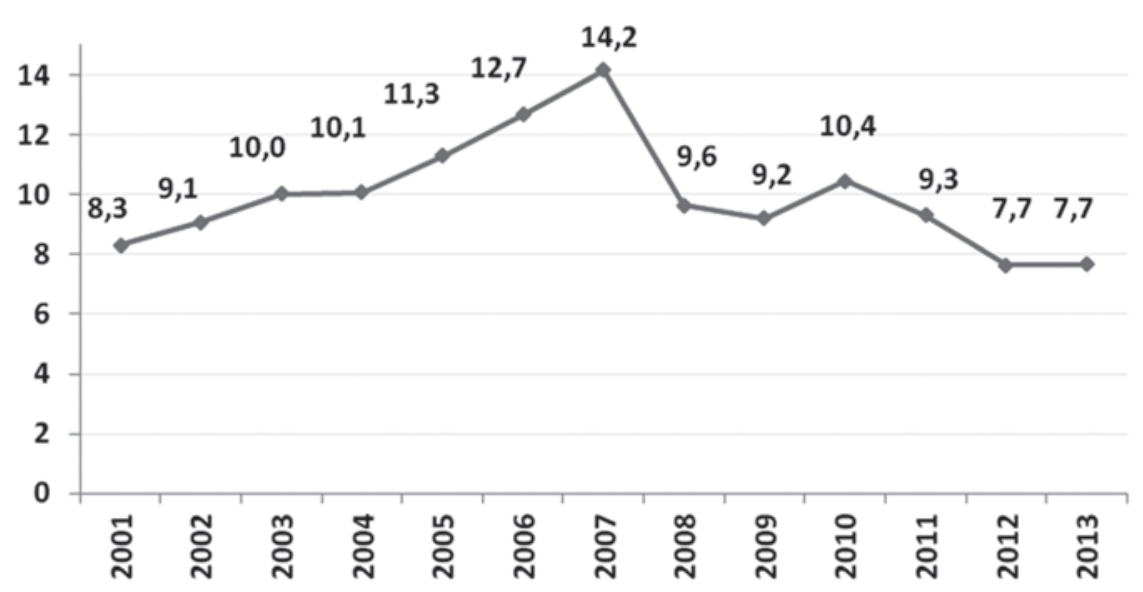

Forrás: Saját szerkesztés,IMF adatai alapján (2014) 
egy olyan évben sikerült elérni, amikor a kínai gazdaság a korábbi évekhez képest lassabb ütemben bóvült. A magyar import a távol-keleti országból 4,4\%-kal csökkent 2012-ben, így összességében a Kínával szembeni kereskedelmi deficit 2,8 milliárd euró volt, ami közel 400 millió eurós javulást jelent 2011-hez képest (MFB, 2013).

Azonban nemcsak az üzleti élet, hanem a kultúra és az oktatás területén is látható fejlődés az országok kapcsolatai között. Az elmúlt években három Konfuciusz Intézet nyílt Magyarországon (a legújabb a Miskolci Egyetemen, 2013 augusztusában), melyek elsôsorban a kínai nyelv és kultúra megismertetésével foglalkoznak.

Mindezek után senki sem csodálkozik azon, hogy egyre több munkavállaló érkezik hazánkba ebból a hatalmas munkaerővel rendelkező országból. (2013-ban Kína lakossága 1,361 milliárd fó volt [IMF, 2014]). Vajon milyen kulturális sajátosságokkal rendelkeznek a kínaiak? Milyen értékek fontosak számukra a munkahelyen? Milyen alternatív módszerekkel motiválhatják óket vezetóik? Jelen tanulmány e kérdésekre próbálja megadni a választ oly módon, hogy az egyik legismertebb, kultúrák összehasonlításával foglalkozó társadalomtudós, Geert Hofstede munkáját, valamint kulturális elméletének dimenzióit hívja segítségül.

\section{Hofstede dimenziói}

Számos, a kultúrákat összehasonlító és a kultúrák közötti motivációs különbségeket is bemutató kutatást végeztek már társadalomtudósok. Jelen tanulmány szempontjából a legfontosabb vizsgálatokat Hofstede publikálta. Kutatóként az elsốk között mérte a kultúrák közötti különbségeket, valamint munkássága az egyik legátfogóbb kultúrákat összehasonlító vizsgálat alapjául is szolgált (lásd GLOBE).

Pontosan mire terjedt ki Hofstede kutatása? „Kicsit sarkosan fogalmazva: a multinacionális szervezet kultúrája érvényesül-e a lokális nemzetközi-etnikai kultúrák befolyása ellenében helyi szinten is, vagy a befogadó környezet sajátosságainak dominanciája miatt nem alakulhat ki egységes kultúra a multinacionális szervezet egészében sem. Hofstede kutatásait annak a kérdésnek a megválaszolása is motiválta, hogy a mégoly sikeres vezetési módszerek, és/vagy »erôs«vállalati kultúrák receptjei átvehetốk, hasznosíthatók-e eltérô kulturális környezetben. " (Klein, 2007: 482. old) Hofstede weboldala (2010a) a következók szerint ír a kutatóról és modelljéról: Geert Hofstede nagy elemszámú alkalmazotti mintától származó pontértékeket analizált, mely adatállományt az IBM alkalmazottjai- tól gyújtötte össze 1967 és 1973 között több mint 70 országban. Kezdetben csak a 40 legnagyobb ország adatait használta, majd a kört kiterjesztette 50 országra és 3 régióra. Hofstede kutatásának 2001 óta megjelent kiadásaiban a pontszámok már 74 országra és régióra lettek publikálva, melyek alapjául részben a különbözó nációkat vizsgáló IBM-tanulmány ismétlései és kiterjesztései szolgáltak.

A kezdeti eredményekboól és a késóbbi kiegészítésekból Hofstede egy olyan modellt fejlesztett ki, amely négy alapvetố dimenziót hoz létre a kultúrák megkülönböztetésének segítésére: Hatalmi távolság, Individualizmus, Férfiasság és Bizonytalanság kerülése. Modelljéhez késóbb egy ötödik (majd egy hatodik) dimenziót is hozzáadott egy újabb nemzetközi tanulmány lefolytatása után. Az ötödik dimenziót Hosszú/rövid távú gondolkodásnak nevezte el, míg a hatodik dimenziót Engedékenység/Visszafogottságnak. Hofstede (1980) a következóképpen definiálja a saját maga alkotta dimenzióit, illetve hozza összefüggésbe azokat a motivációval, motiválással (1996):

\section{Hatalmi távolság (Power Distance)}

A nemzeti kultúra első dimenziója a Hatalmi távolság. Ez megmutatja, hogy egy társadalom milyen mértékben fogadja el azt a tényt, hogy az intézményekben és szervezetekben jelenlévő hatalom elosztása egyenetlen. Tükröződik mindez a társadalom legkevésbé befolyásos és a befolyásosabb tagjainak értékeiben egyaránt. Az ebben a dimenzióban alacsony értéket elérô kultúrákban a hatalom (és annak motivációban betöltött szerepe) a pozíción, a szakértelmen és a különböző javak adásának lehetőségében rejlik, míg a nagy hatalmi távolsággal rendelkezők esetében a hangsúly a család, a barátok, a karizma és az erô használatának képességében van. Míg az előbbieknél az alkalmazottak szerepére és motiválására fókuszálnak, addig az utóbbiaknál a menedzserek szerepe kerül előtérbe.

Individualizmus - kollektivizmus (Individualism Collectivism)

A második dimenzió magában foglalja az individualizmust és ellentétét, a kollektivizmust. Az individualizmus egy olyan lazán körvonalazott társadalmi keretet jelent, melyben az emberektól elvárják, hogy csak és kizárólag magukra és közeli családtagjaikra felügyeljenek. Ezzel szemben a kollektivizmust egy szoros társadalmi keretként lehet jellemezni, amelyben az emberek megkülönböztetik a csoporton belülieket és a csoporton kívülieket; elvárják, hogy a csoporton belül (a rokonok, klánok, szervezetek) gondoskodjanak róluk, amiért ók cserébe abszolút lojalitással tartoznak. A kollektivis- 
ta és az individualista társadalmakban is motiválható a dolgozó elóléptetéssel, de nem ugyanazon a módon. Míg a kollektivista társadalmakban az elóléptetéssel kapcsolatos döntés során az egyén csoportjának teljesítménye a mérvadó, addig az individualista társadalmakban az egyéni teljesítmény és az ahhoz szükséges képességek megléte kerül előtérbe. Előbbieknél a „Mi” szerepe a döntő, míg az utóbbiaknál az „Én” szerepe megkérdőjelezhetetlen.

\section{Férfiasság - nóiesség (Masculinity - Femininity)}

A harmadik dimenzió a Férfiasság, mely fogalom magában hordozza ellentétes pólusát, a Nóiességet is. A dimenzió kifejezi annak a mértékét, hogy a társadalomban az olyan férfias értékek, mint a magabiztosság, a pénz és tárgyak megszerzése, mások érdekeinek figyelembevételének hiánya, az élet vagy az emberek „minősége” mennyire dominánsak. A felsorolt értékeket férfiasnak bélyegzik, köszönhetóen annak, hogy szinte minden társadalomban a férfiak magasabbra pontozzák azokat. Amennyiben egy társadalom tagjai jóval inkább a férfias oldalra pontoznak, abból az következik, hogy szélesebb a szakadék annak férfi és nói értékei között. Míg a férfias kultúrákban a motivációs tényezốk között leginkább a tő́ke, a teljesítmény, az előrelépés lehetôsége a hierarchiában, valamint a kollégák közötti verseny lehet motivátortényezó, addig a feminitást inkább elfogadó kultúrákban az egyenlóség, a szolidaritás és az életkörülmények szerepe lehet meghatározó motiváló erō.

\section{Bizonytalanság kerülése (Uncertainty Avoidance)}

A negyedik dimenzió a Bizonytalanság kerülése, amely megmutatja, hogy egy társadalom mennyire érzi magát veszélyben bizonytalan és félreérthető helyzetek során. Rávilágít arra, hogy a társadalom milyen mértékben próbálja meg elkerülni ezeket a szituációkat nagyobb karrierstabilitás biztosításával, több formális szabály létrehozásával, vagy éppen azzal, hogy nem tolerálja a deviáns ideákat, viselkedésformákat, és hisz az abszolút igazságokban, valamint a szakértelemben. Azon társadalmak, melyekben a bizonytalanság kerülése erôsen jelen van, magasabb fokú szorongással és agresszivitással is jellemezhetőek, mely többek között erôs belső késztetést idéz elő az emberekben arra, hogy keményen dolgozzanak. A dolgozók motiválása az ebben a dimenzióban alacsony értéket elérô országokban a teljesítmény, a tisztelet és különböző juttatások útján történik, ezzel szemben az erós bizonytalanságkerüléssel jellemezhetố országokban a motiválás lehetôsége a teljesítményrốl áttevődik a biztonságra (a munkahely biztonságára, a szabályok adta keretek biztonságára és fontosságára).
Hosszú távú - rövid távú gondolkodás (Long - Short Term Orientation/Confucian Dynamism Index)

Ezen ötödik és az elôzô négyhez képest csak késóbb megalkotott dimenzióját így definiálja a szerzó (Hostede, 2010a): „Ezt az ötödik dimenziót egy olyan tanulmányban fedeztem fel, melyet világszerte 23 ország diákjai között végeztek egy olyan kérdőív segítségével, melyet kínai tudósok dolgoztak ki. A dimenzió olyan értékeket tartalmaz a hosszú távú orientációhoz kapcsolódóan, mint a takarékosság és a kitartás, míg a rövid távú orientációhoz kapcsolódóan olyanokat, mint a hagyomány tisztelete, a társadalmi elvárások teljesítése és mások »bőrének « mentése. A dimenziónak mind a pozitív, mind a negatív értékei megtalálhatók Konfuciusz (a legbefolyásosabb kínai filozófus) tanításaiban."

A hosszú távú gondolkodású társadalmakban motiváló hatása lehet az olyan jövốben jelentkezó jutalmaknak, melyeket pragmatikus erények képviseletével lehet elérni. Ide tartozik például a kitartás és a változó körülményekhez való adaptáció is. Ezzel szemben a rövid távú gondolkodású társadalmak sokkal inkább a múlt és a jelen felé fordulnak. Olyan értékeknek lehet motiváló hatása, mint a nemzeti és vállalati hovatartozás, büszkeség, tradíciók elfogadása és a tekintély tisztelete (nemcsak a társadalomban, hanem a munkahelyen is), valamint a társadalmi (és vállalati) kötelességeknek és kötelezettségeknek való megfelelés (Hofstede, 2010b).

Engedékenység - visszafogottság (Indulgence - Restraint)

Minkov bolgár kutatóval végzett további kutatásai során Hofstede egy hatodik dimenziót is azonosított. Az Engedékenység (vagy élvezet, megengedés), illetve ellentéte, a Visszafogottság (vagy önuralom) dimenziója esetében a kultúrákat az alábbiak alapján különbözteti meg: vannak, amelyek elnézóek és elfogadóak az élet élvezete és a szórakozás terén, míg mások visszafogottabbak a szigorú szociális normáknak köszönhetően (Hofstede et al., 2010).

Az engedékenységgel bíró társadalmak lehetôvé teszik az élet élvezetét és a szórakozást az alapvető és természetes emberi szükségletek szabad kielégítésének révén (az ilyen légkörú munkakörnyezet motiváló hatású lehet az ezekben a társadalmakban múködő vállalkozásoknál). Míg a visszafogottsággal jellemezhetô társadalmakban szigorú normák segítségével kerülnek elfojtásra az örömteli szükségletek (a túlzott engedékenység és a normáktól való eltérés az ilyen vállalkozások esetében demotiválhatja dolgozóikat munkahelyükön) (Hofstede, 2012). 


\section{Hofstede és a GLOBE}

Szintén nagy horderejű és széles (62 országra kiterjedő) mintán elvégzett kultúrák közötti kutatás a Global Leadership and Organisational Behaviour Effectiveness (röviden GLOBE). „A GLOBE-kutatás egy kiterjedt nemzetközi kultúra- és vezetésistílusfelmérés, amelyben ma már több mint ötven ország kutatói vesznek részt (Magyarországon Bakacsi és Takács [1998] vezetésével folyt a vizsgálat)." (Hunyady - Székely, 2003: 500. old.) A GLOBE kvantitatív módszerrel a szervezeti kultúra kilenc dimenzióját különítette el, melyek magukban foglalják a Hofstede által azonosított dimenziókat is. Erról Hofstede így ír: „A GLOBE nemcsak hogy adoptálta a paradigma dimenzióit, hanem az én ötös választásomból indultak ki, elvi okok miatt azonban ezeket kilencre terjesztették ki. Alkalmazták a Hatalmi távolság és a $B i$ zonytalanság kerülésének címkéit (de nem feltétlenül azok jelentését). A Kollektivizmus fogalmát kettéválasztották Intézményi kollektivizmusra és Csoportkollektivizmusra, a Férfiasság - Nóiesség fogalmát pedig Asszertivitásra és Nemi egyenlőségre. A Hosszú távú gondolkodást (orientációt) Jövőorientációra változtatták, és két további dimenziót jelenítettek meg: a Humánorientációt és a Teljesítményorientációt." (Hofstede, 2006: 883. old.).

A GLOBE-kutatás az alábbiak szerint definiálja vizsgált dimenzióit:

„Hatalmi távolság (Power Distance): annak a mértéke, hogy egy szervezet vagy a társadalom tagjai menynyire várják el és fogadják el a hatalom egyenlőtlen eloszlását, hogy a hatalom a szervezet vagy kormány magasabb szintjére rétegződjön és oda koncentrálódjon.

Bizonytalanság kerülése (Uncertainty Avoidance): annak a mértéke, hogy egy szervezet vagy a társadalom tagjai kialakult társas normákra, rituálékra és bürokratikus gyakorlatra támaszkodva mennyire törekszenek a bizonytalanság elkerülésére, mérsékelve ezzel a jövőbeli események előrejelezhetetlenségét.

Intézményi kollektivizmus (Institutional Collectivism): annak a mértéke, hogy a szervezetek és a társadalom intézményi normái és gyakorlata mennyire bátorítják és jutalmazzák az erőforrások kollektív elosztását és a kollektív cselekvést.
Csoportkollektivizmus (In-Group Collectivism): annak a mértéke, hogy az egyének szervezetuikben vagy családjukban mennyire juttatják kifejezésre büszkeségüket, lojalitásukat és összetartozás-érzésüket.

Nemi egyenlóség (Gender Egalitarianism): annak a mértéke, hogy a társadalom vagy egy szervezet menynyire minimalizálja a nemi szerepek közti különbségeket elősegítve ezzel a nemek közötti egyenlőséget.

Asszertivitás/rámenôsség/magabiztosság (Assertiveness): annak a mértéke, hogy az egyének társas kapcsolataikban mennyire határozottak (asszertívak), szembenállóak (konfrontatívak) és agresszívek szervezeteikben vagy a társadalomban.

Teljesítményorientáció (Performance Orientation): annak a mértéke, hogy egy szervezet vagy a társadalom mennyire bátorítja a csoporttagokat a teljesítmény növelésére és a kiválóságra, és mennyire jutalmazza óket ezért.

Jövóorientáció (Future Orientation): annak a mértéke, hogy egy szervezet vagy a társadalom tagjai milyen mértékben adják a fejüket olyan jövőorientált magatartásformákra, mint a tervezés, a jövớbe való befektetés, a javak egyéni vagy kollektív felélésének elhalasztása.

Humánorientáció (Humane Orientation): annak a mértéke, hogy a szervezetek vagy a társadalom tagjai mennyire bátorítanak és jutalmaznak másokat arra, illetve azért, hogy igazságosak, méltányosak, önzetlenek, barátságosak, nagylelkúek, gondoskodók és kedvesek legyenek" (Mikulás, 2011: 9-11. old.)

A GLOBE-kutatás eredményeit összefoglaló kötet (House et al., 2004) Kínára vonatkozó eredményeit a 2. ábra szemlélteti (az adatok egy 1-tól 7-ig terjedó Likert-skálán értelmezendőek).

2. ábra

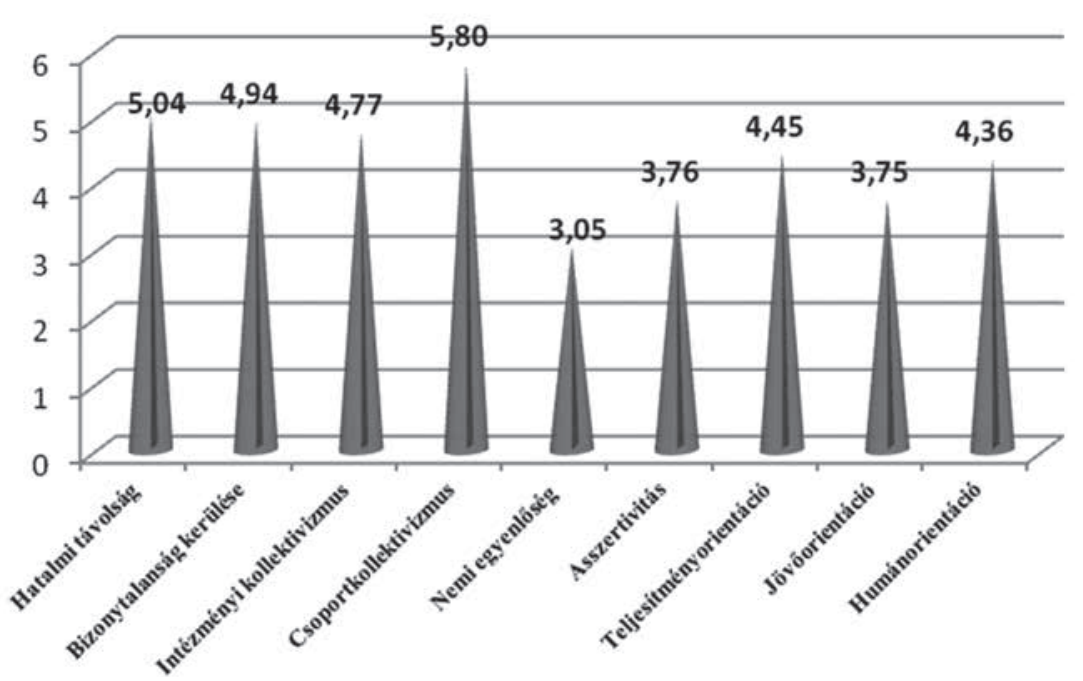

Forrás: saját szerkesztés, a GLOBE-kutatás adatai alapján (House et al., 2004) 
Hofstede (2006: 883-885.) hét pontban sorolja fel a saját és a GLOBE-kutatás közötti hasonlóságokat és különbségeket, melyek rendre a következók: 1. új adatok - már létezó adatok; 2. egyéni kutató - kutatócsoport; 3. vezetốk - alkalmazottak; 4. elméletvezérelt elemzés cselekvésvezérelt elemzés; 5. Amerikai Egyesült Államok által inspirált - megfelelôen felülvizsgált kutatás; 6. szervezeti kultúra - társadalmi kultúra; 7. része vagy előzménye a nemzeti kultúrának a nemzeti jólét. Az előzőeken túl további faktoranalízisekkel is igyekszik megerôsíteni a két kutatás közötti különbséget, illetve kritikai észrevételeit feltárni. Tanulmányára hamarosan megszületik a válasz a GLOBE kutatói részéról (Javidan et al., 2006: 910. old.), akik többek között hofstedei hegemóniáról és a kutatási adatok idóbeli elavultságáról (35 év) írnak. További kritikai észrevételek a következő alfejezetben kerülnek kifejtésre.

\section{A hofstedei dimenziók kritikái}

Hofstede elméletét több kritika érte, elsősorban a minta megválasztása, a mintavétel módja, a vizsgálat módszertana, valamint az eredmények idóbeli változatlanságának feltételezése miatt. Hazánkban Primecz Henriett (1999: 112-113. old.) gyújtötte össze, „Hofstede - más szemmel" címú tanulmányában a kutatás kritikai észrevételeit:

a) „Hofstede és kutatótársai kizárólag IBM-es dolgozókat kérdeztek meg, és egész társadalmakra vonatkozó következtetéseket vontak le"... holott ... ,az IBM-dolgozókat a legnagyobb jóindulattal sem tekinthetjük a társadalmakat jól reprezentáló csoportnak."

b) A kutatás az 1960-as évek végén, a 70-es évek elején zajlott, és Hofstede amellett érvelt, hogy a kultúra viszonylag változatlan az idő́k során, azonban ez mellett nem hozott fel komoly érveket.

c) „Számos ország, ahol nem volt IBM-vállalat, kimaradt a kutatásból, így például a kelet-európai országok és a volt Szovjetunió.”

d) „Egy kultúrának tekintette az olyan országokat is, ahol egyértelmúen és jól elkülöníthetően különböző kultúrák élnek egymás mellett például a flamandok és a vallonok Belgiumban."

e) Megjelenik nála a „sztereotípiák problémája: amikor a kollektív szintról következtetünk az egyénre".

f) A megalkotott dimenziók nem univerzálisak.

A fenti kritikákon túl Primecz is elismeri, hogy Hofstede kutatása az egyik „legalaposabb és legszélesebb körben gyújtött” kutatás, és „Hofstede dimenziói kétségtelenül jó vezérvonalként szolgálnak a kulturális diverzitás megértéséhez" (Primecz, 1999: 114. old.). Megjegyzi továbbá, hogy „Hofstede módszerét sokan kritizálták, de - meggyőződésem szerint - éppen azzal tett legtöbbet a komparatív kultúrakutatásért, hogy egy más célú kérdőívvel olyan dimenziókat tárt fel, amit más módszerrel nem tudott volna. Ilyen típusú adatgyújtésnél a kutatónak nagyon más választása nincs is: faktoranalízissel próbálta az adathalmazból kibontani, hogy az egyes kérdésekre adott válaszokat befolyásolja-e a nemzeti hovatartozás". (Primecz, 2006: 6. old.) A fenti megállapításokkal összhangban lévő további kritikai észrevételek a következók:

1. A modell meglehetôsen régi. Az adatok többsége az 1967 és 1973 között idôszakból származnak (igaz, késóbb végeztek újabb felméréseket), az ettôl az idôponttól napjainkig eltelt időszakban mind az emberek, mind motivációik sokat változtak, változhattak. Nemcsak az emberekkel történtek változások, a világ is más lett, ahogy a motivációs késztetések és a világ nemzeteinek néhány „alaptulajdonsága" is. A vizsgálat napjainkban történő megismétlése nagy valószínúséggel jelentős eltéréseket mutatna a korábbi eredményekhez képest, ami a kultúrák töretlen fejlődését is bizonyítaná.

2. Azok az emberek, akiket az IBM foglalkoztat, nem tudják képviselni egy nemzet teljes társadalmát. Még ha a legmodernebb statisztikai modellt is alkalmazzuk, egészen biztosan eltér majd a valóságtól. Rengeteg ember nem tud, vagy egyszerúen nem akar az IBM-nél dolgozni, így a cég nem is képes reprezentálni a teljes népességet.

3. „Triandis szerint a dimenziók sokkal inkább munkához kapcsolódó értékeket tükröznek, mintsem nemzeti értékeket" (Kopfer-Rácz et al., 2013: 4. old.).

4. „A legtöbb akadémikus azt kifogásolja, hogy az egyes országokat kulturálisan homogénként kezeli, és az egyes kultúrákat nemzethatárok alapján különbözteti meg." (McSweeney, 2002; Kopfer-Rácz et al., 2013: 4. old.)

5. Hofstede weboldalán (Hofstede, 2010b) az áll, hogy „bár maguk a dimenziók nem léteznek - de jó szolgálatot tehetnek". Hofstede hangsúlyozza, hogy a kultúrák dimenziói kézzelfogható értelemben nem léteznek. Ezek konstrukciók. Egy konstrukció közvetlenül nem megfigyelhető, hanem következtetni lehet rá verbális kijelentésekból, egyéb viselkedésformákból, és hasznosíthatóak abban az értelemben, hogy egyéb megfigyelhetô és lemérhető verbális és nem verbális visel- 
kedésformák megjósolhatóak legyenek belőlük (Levitin, 1973). A kultúra maga nem egy szerkezet, nem úgy, mint maguk az értékek. Nincs értelme megkérdezni, hogy egy kultúrának mennyi dimenziója létezik? Ez olyan, mintha azt a kérdést tennénk fel, hogy hány fajta felhô létezik? Mindez meghatározás kérdése. Hofstede talán éppen azért napjaink egyik legtöbbször hivatkozott társadalomtudósa, mert modelljének nemcsak értékeit, hanem hiányosságait is elismeri.

\section{Hofstede dimenzióinak értékei Kínában}

Az olyan magas hatalmi távolsági értékkel rendelkezô országokban, mint Kína, az alkalmazottak úgy gondolják, a vezetônek kell megmondania, hogy a beosztottnak mit kell pontosan tennie és ezért alkalmatlannak is tartják magukat arra, hogy változtatásokat javasoljanak a menedzsereknek. (A hofstedei dimenziók kínai értékeinek és a világátlagoknak (származtatott adat) a különbségeit a 3. ábra szemlélteti.)

Hofstede dimenzióértékei Kínában és a világátlaghoz viszonyítva

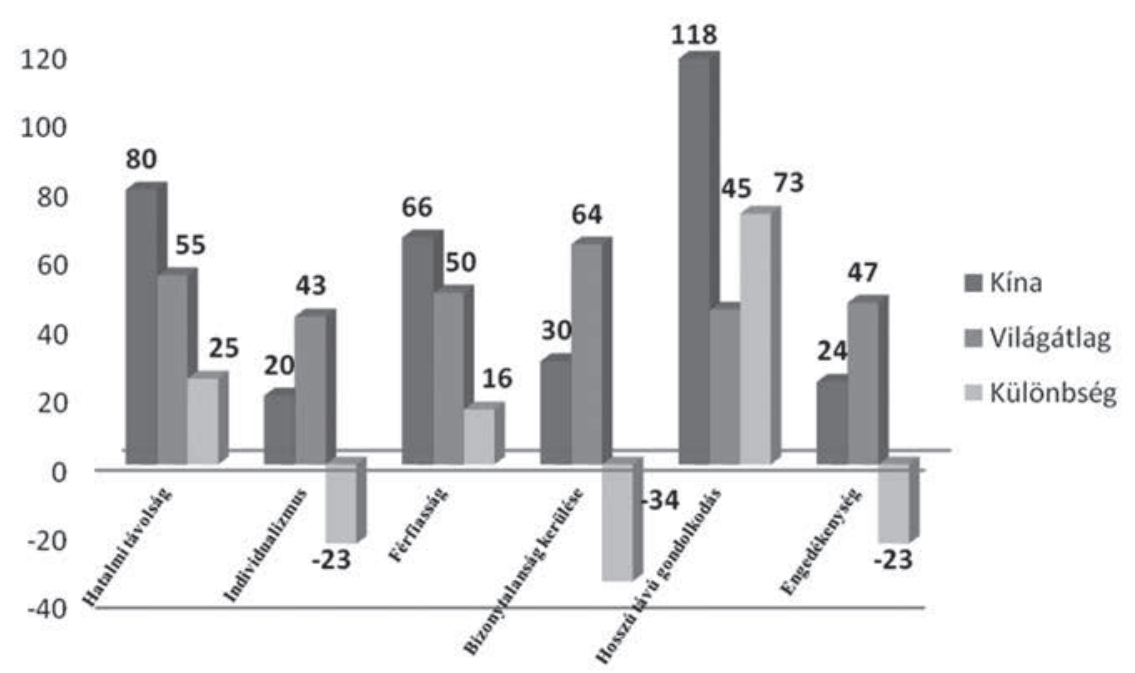

Forrás: saját szerkesztés, Hofstede adatai alapján (2010a és 2012) jellemvonás. A kollektivista társadalom továbbá erôs kapcsolatokat is szorgalmaz, ahol mindenki felelősséget vállal a csoport egyes tagjaiért (Hofstede, 2010a). A férfiasság terén elért magas pontszám arra utal, hogy a kínai munkavállalók életében (így motiválásában is) nagy szerepe van a magas béreknek és az egyéni teljesítményeknek (King-Metters - Metters, 2013). Az olyan viszonylag ,alacsonyabb” bizonytalanság kerülése értéknél, mint amilyen Kínában tapasztalható, az emberek szerint a bizonytalanság természetes dolog, az élet velejárója, a kemény munka önmagában dicsôség, az agresszív viselkedés nem elfogadott, és az érzéseket sem feltétlenül kell kimutatni (Csath, 2008). Hofstede analízise szerint Kína a hosszú távú gondolkodású országok egyik mintapéldája, igaz azonban, hogy a dimenzió magas értéke jellemző az ázsiai kultúrák többségére. Maga a dimenzió egy társadalom időperspektíváját és kitartását is jelzi egyszerre. Kitartás, mely legyőzi az idő adta olyan akadályokat, melyek legyőzése akarattal és erővel már nem megy. Az engedékenység dimenziójának értéke Kína esetében meglehetősen 3. ábra alacsony (24), ami szigorú szociális normáknak való megfelelésre és annak elfogadására utal.

\section{Kínai munkavállalók mo- tiválásának alternatívái - Hofstede kulturális dimenzió- inak tükrében}

A hofstedei dimenziók alábbi felsorolásában kerülnek bemutatásra a kínai munkavállalók motiválásának alternatívái oly módon, hogy azokban több, a témában jártas szerző vonatkozó munkái lettek integrálva.

Hatalmi távolság: Kínában magas a hatalmi távolság mértéke (Hofstede, 1984), ami nagy hierarchikus rendet takar, mi-

A kínaiak egyedül az individualizmus területén kaptak kevesebb pontot, mint más ázsiai országok. Az individualizmushoz viszonyítva ez nagy valószínúséggel a kommunista szabályok által meghatározott kollektivista társadalom fontosságának hangsúlyozásából ered. Az individualizmus alacsony értéke nyilvánvaló egy egymással szoros kapcsolatban álló és odaadó tagokból álló csoportban, legyen az egy szúk, vagy éppen egy kiterjedt családi vagy más családon kívüli viszony. İgy a húség egy kollektivista kultúrában az egyik legfontosabb vel a hatalom a hierarchia csúcsán lévố néhány ember kezében összpontosul. A kínai vezetók hatalma megkérdőjelezhetetlen, egy szervezet élén a vezető gyakorlatilag „mindenható”. Szretykó (2013) szerint a kínai vállalatok élén álló vezetô hatalma abban nyilvánul meg, hogy a beosztott nem kérdójelezheti meg a vezető utasításait, azokat igyekszik maradéktalanul követni (Juhász, 2014: 73. old.). A legtöbb kultúrában összefüggés van egy ország vallása és Hofstede dimenziói között. Hofstede dimenziói 
közül a magas hatalmi távolsági index értéke az, ami leginkább kapcsolatban áll a hindu vallás elterjedésével, csakúgy, mint a kínai ateisták és a muszlimok esetében is. Mindháromra jellemző a magas fokú hatalmi távolsági index (Thakur, 2009). „A konfucianizmus alapján az emberi kapcsolatok helyes kezelése a harmónia egyik alapfeltétele, így a kínaiak természetesnek tekintik, hogy a fónök magasabb szinten helyezkedik el a beosztottnál. A vállalaton belül megvalósuló harmónia alapja tehát a nagy hatalmi távolság, a fơnök (aki Kínában általában maga a tulajdonos) megkérdójelezhetetlen hatalma. A beosztott feltétel nélkül elfogadja a főnök utasítását, véleményét, nem értelmezi, vagy vizsgálja felül azokat. Az alkalmazott számára nem létezhetnek »miért?«-ek. Ennek gyökereit szerintem a »tianming « elképzelésben kell keresnünk, melynek alapján az uralkodó az Ég küldetését teljesítve került a trónra. A vezetô nem véletlenül került pozíciójába, annak biztos megvan a nyomós oka, ezért képtelenség tekintélyét kétségbe vonni." .... Az ideális főnök eszményképe tehát Kínában ,a bölcs, jóindulatú atyai figura, aki bár nem hagy nagy mozgásteret alkalmazottjainak, de azok így legalább mentesülnek a döntéshozatal felelőssége alól. ..... A túl közvetlen vezetô hamar elvesztheti..... tekintélyét, és nehezebben tudja majd irányítani kínai beosztottjait." (Váradi, 2008: 31. old.) Szretykó szerint (2013) munkavállalók olyannyira lojálisak vezetőikhez, hogy igyekeznek a még mindenki számára egyértelmúen hibás vezetôi utasításokat is maradéktalanul követni. Ezzel próbálják megóvni a számukra oly fontos ,arc" kultúráját, ami egyfajta megtiszteltetést, társadalmi elismerést jelent (Juhász, 2014: 73. old.). Meg kell azonban azt is említeni, hogy egy alkalmazott jutalmazása nemcsak magasabb bérrel, hanem hatalma megnövelésével is elérhető. Ez hatással van a keleti munkavállalók karrierlehetőségekkel vagy más jutalmakkal történő ösztönzésére is. Ha mindezt nem veszik figyelembe a vezetók, az óriási félreértésekhez vezethet a keleti munkavállalók motiválásakor (Lemoine - Jansson, 2010).

Individualizmus/kollektivizmus: „A távol-keleti emberre annyira jellemző a kollektivizmus, hogy nem is képes kollektívák keretein kívül élni. Vagyis az egyén individuum szerepe itt jóval gyengébb, mint a nyugat-európai társadalmak esetében. A kínaiaknál a vérségi kötelékek döntő szerepet játszanak. A Távol-Keleten az egyéni célok kevésbé jönnek számításba, nincsenek egyéni kiválóságok, zsenik és hôsök. Ugyancsak fontos érték számukra a harmónia. Atengerentúli kínaiak szerint a rend fenntartása a kapcsolatokra vonatkozó erkölcsi eloóírások betartásán alapul.
A konfuciánus tanítás alapján az egyénnek magának kell gondoskodnia arról, hogy a társadalmi kötelékeiben a harmóniát fenntartsa és biztosítsa. Elhárítják mások ellenôrzését, kerülik a konfrontációt, így törekednek közvetve a harmóniára." (Szretykó, 2013: 12. old.) A kínai üzleti kultúra leginkább kollektivista gondolkodásmóddal átitatott. Ezek az értékek még inkább láthatóvá válnak, amikor megfigyeljük, hogy a kínai emberek hogyan viselkednek, amikor más emberekkel találkoznak. A kínai üzleti kultúrában az emberek inkább szociális csoportként jellemezhetôek, mint egyénekként, mivel egy személyre Kínában sokkal inkább egy társadalom vagy kulturális környezet részeként tekintenek (Hofstede, 1984). „A motivációt kutató szakemberek között általános az az álláspont, hogy minden embernek nemzetiségtól függetlenül vannak céljai .... Az eddigi kutatások szerint az amerikai munkavállalók leginkább pénzzel motiválhatók, de a munka tartalma, érdekessége sem elhanyagolható szempont a számukra. Az ázsiaiak esetében pedig az elvégzendô munka és a munkavállalók közötti összhang szerepel a motivációs tényezók listájának első helyén.” (Szretykó, 2013: 10. old.) „A kollektivizmus dimenziójánál meg kell említeni a kínai üzleti életben oly fontos ,guanxi’'-t. Ez egyfajta egymással szembeni jóindulatot jelent, amelyben a win-win gondolkodás elemeit lehet felfedezni, amolyan „te is jól jársz - én is jól járok” szemlélet. Csath (2008: 300. old.) szerint a guanxi versenyelónyt jelenthet azok számára, akik élni tudnak vele. A guanxi egyfajta testvériességet (mely tipikus kollektivista vonás) és igazságosságot is takar, amit feltétlenül figyelembe kell venni a külföldi vállalkozások vezetóinek is, mivel motivációs szerepe az üzleti életben megkerülhetetlen.” (Juhász, 2014: 74. old.) „Családi vállalat esetén megvan a kellố motiváció a minôségi és hatékony munkavégzésre, hiszen a bevétel ennek a függvénye, és a hatékonyabb munka által a család is több forráshoz jut. Kellô motiváltság esetén kevés szorgalmasabb, tájékozottabb, szemfülesebb munkavégző akad a kínaiaknál. Ez igaz a multinacionális vállalatok csúcsvezetóitől kezdve egészen a külföldön szerencsét próbáló, saját vállalkozásba kezdő kínaiig." (Váradi, 2008: 38. old.) „Ellenkezó esetben viszont folyamatos ellenőrzésre és kontrollra van szükség, hogy a munkavállaló megfelelő színvonalon teljesítse feladatát." (Juhász, 2014: 74.) „Egy felmérés ki is mutatta, hogy a kínaiak sokkal hatékonyabban múködnek csoportban, névtelenül, mintha nevüket felvállalva, egyénileg kéne ezt megtenniük. (Egyértelmú tehát ebben az esetben is, hogy a kínaiak esetén a nyugatitól eltéró ösztönzố rendszerre van szükség a foglalkoztatás során.) Részben emiatt is a kínai delegációk, tárgyalócsoportok jellemzóen elég 
nagy létszámúak.” A kínaiak esetében ,,a kemény munka fố motivációja nem elsôsorban a teljesítmény, hanem a csoport tiszteletének, elfogadásának kivívása és a család jóléte" (Váradi, 2008: 32. és 44. old.).

Az előző dimenziónál már említett ,arc” kultúrája itt is érvényesül: „Ezen a földrészen az ember valamely csoport tagja, élete és munkája során befektet ebbe a csoportba, viszont ha nem tud megfelelố módon hozzájárulni a csoport teljesítményéhez, elveszíti az arcát. Ezért a kínaiak nagy jelentőséget tulajdonítanak annak, hogy ki, mit gondol róluk. Egy menedzser szerint az arc elvesztése sokkal erôsebb hatással van az emberekre, mint bármely fizikai félelem. ..... Ez a vállalaton belüli viszonyokra is igaz. ..... a vezetố a beosztottjának sem mondhatja meg direkt módon, hogy hibázott. Erre közvetett módon kell utalnia, mert ha nem így tesz, akkor a beosztott elveszíti az arcát, vagyis annak a munkának az értékét, amit addig a csoportba fektetett. Annak a pozíciónak az elérése, amely mások által is elismert, fontosabb, mint Nyugaton, ugyanakkor a pénzbeli elismerés kevésbé számít, mint a nyugati menedzserek esetében." (Szretykó, 2013: 12. old.)

Nóiesség/férfiasság: A kínai nemzet férfiasabb vonásokat mutat az átlaghoz képest, ezt a férfias, határozott fellépést a munkahelyen el is várják a beosztottak vezetőiktốl. A jó vezető így kellóen férfias dominanciával, autokratikus módon kiadott csoportfeladatokkal tudja leginkább motiválni munkatársait Kínában. (Megjegyzendő azonban, hogy minél magasabb egy ország férfiasságdimenziója, annál nagyobb a szakadék a férfiak és nók között, bár ez a szakadék érdekes módon egy sokkal versenyképesebb és magabiztosabb nôi populációt is generálhat.)

„A nối szerepek alakulása a térségben nagyon sajátos HRM-kérdés. Ebben a tekintetben a Kínai Népköztársaság elóbbre tart, hiszen a kommunista irányítású országban a nók foglalkoztatását kiemelten kezelik a legkülönbözóbb ágazatokban. Ugyanakkor megállapítható, hogy ebben a térségben a nók munkahelyi megkülönböztetése és diszkriminációja általános jelenség még napjainkban is.” (Szretykó, 2013: 14. old.) Kína egy viszonylag férfias nemzet, így a kínai férfiak öntudatosak, ambiciózusak, kitartóak, és azért élnek, hogy dolgozhassanak. A kínai szervezetekben nagyon erős a hierarchikus rend, ahol a hatalom a hierarchia csúcsán lévő néhány ember kezében összpontosul (Heidrich, 2006). „A kínai munkavállalók motiválásában egyértelmúen a férfias értékeknek megfelelő eszközök használatával érhetnek el sikereket a vezetók. Így a nyereség, a pénz hajszolása, a vállalat munkatársainak kizsákmányolása a vagyon felhalmozására való törekvés, mind - mind meghatározó a kínai vállalatok és munkavállalóik motiválása során. Extrém esetben a célok elérésében megjelenik a csalás, a kormánnyal való szembehelyezkedés, az adócsalás, a korrupció, a guanxi kenópénzzel való megolajozása is (Marosi, 2003). A pozícióknak és rangoknak, titulusoknak (melyek további maszkulin értékek) és a hozzájuk kapcsolódó tiszteletnek szintén meghatározó szerepe van a dolgozók ösztönzésében. Itt kell megemlíteni az extrém mértékú költekezést is, mely az üzleti partner luxuscikkekkel történő elkápráztatását és ezzel üzletkötésre történő motiválását jelenti (Váradi, 2008). „A maszkulinitás előtérbe helyezése és a feminitás elnyomása megjelenik a nő́k gazdasági szerepvállalásának ösztönzésében is, melyet elősegít az egy gyermek vállalását előtérbe helyező „,egyke politika”. Ez lehetôvé teszi, hogy a kínai nók ne csak a gyermeknevelésben és a háztartás vezetésében, hanem a üzleti életben is kiteljesedjenek." (Juhász, 2014: 74. old.)

Bizonytalanság kerülése: Minél alacsonyabb a bizonytalanság kerülésének értéke, a kultúra annál nyitottabb a strukturálatlan ötletekre és szituációkra, illetve tagjai nem próbálják meg kontroll alatt tartani minden ismeretlen és váratlan eseményt vagy helyzetet, míg a bizonytalanságot kerüló országok népességének körében ez sokkal inkább megfigyelhető (Hofstede, 2010a). Általában az alacsony érték (így a kínai érték is) tekinthető ,jobbnak", mivel ez azt jelenti, hogy a társadalomnak kevesebb szabálya van, és nem próbál meg kontrollálni minden eredményt és következményt. Így ez nemcsak az ötletek, gondolatok és képzetek nagyobb fokú toleranciáját, hanem a „kétértelmúség” magas toleranciáját is jelenti (Thakur, 2009). A hatalmi távolság értéke a kínai szervezeteken belül igen magas, ami hatással van a bizonytalanság kerülésének megítélésére is. A hatalommal nem rendelkezô emberek egy ilyen társadalomban elfogadják és tudják, hogy a társadalomból csak néhány ember rendelkezhet hatalommal (Hofstede, 1983). Az ilyen típusú társadalmakban a jutalmazni kívánt emberek hatalmuk megnövelésével jutalmazhatóak igazán. Ezen tényt a kínai alkalmazottak motiválása során szigorúan figyelembe kell venni (Juhász, 2014: 75. old.). „A kínaiak a kellemetlen helyzeteket élik meg fenyegetésként, inkább elviselik a bizonytalanságot, mint hogy nemet mondjanak, és kínos szituációkat idézzenek elő. A kínaiak az új, szokatlan helyzeteket fenyegetésként értékelik. Például a kínai beosztottak nehezen viselik el, ha döntés elé kerülnek. Az ilyen szituációkra nem tudnak hatékonyan reagálni, mivel megszokták, hogy mindig a fónök dönt." (Szretykó, 2013: 15-16. old.) A kínai bizonytalanságkerülés arra is utal, hogy sok- 
szor halogatják a konkrét válaszadást, a nyílt nemleges válaszadás helyett, ami azokból a nyugati emberekból értetlenséget válthat ki, akiknél az „idő pénz” elve érvényesül (Váradi, 2008).

Hosszú távú/rövid távú gondolkodás: A kínaiak magasan vezetnek ebben a kategóriában, megórizve ezzel a dimenzió Konfuciuszhoz köthető értékeit. Esetükben motiváló ereje lehet a munkahelyi kitartásra való ösztönzésnek és a változó körülményekhez való alkalmazkodás elismerésének. Hofstede szerint a dimenzió ezen oldalát képviselő országokban, így Kínában is a kitartás, a takarékosság, a kapcsolatok státus alapján történő rendezettsége és egyfajta „szégyenérzet” („meghunyászkodás”) jellemzi a munkavállalókat. Fontos továbbá megjegyezni, hogy a kínai embereket meghatározza a változó körülményekhez való jó alkalmazkodás; a más országoktól való tanulási hajlandóság; a megtakarításaik nagy száma és a pénzügyi alapokba történő befektetési hajlandóságuk (Hofstede, 2011). A kínai kultúrában Szretykó szerint is ,a hoszszú távú orientáció a jellemzó, amely a munkatársak, üzletfelek kiválasztásában, az üzleti tárgyalásokban és a foglalkoztatás terén egyaránt megjelenik" (2013: 16. old.). Konfuciusz hangsúlyozta a rend, az egyensúly és a harmónia fontosságát, ami tartást, kitartást, hosszú távra történố gondolkodást takar, de itt kell megemlíteni a vezetốk, feljebbvalók tiszteletét és a másokkal való töródés értékeit is. Az egypártrendszerú Kínában a pártnak fontos az olyan jellegú tanítás, amely arra ösztönzi az állampolgárokat és a beosztottakat, hogy fogadják el helyüket a társadalomban, és ne kérdőjelezzék meg a párt, illetve a vezetố hatalmát (Csath, 2008). Egyértelmú, hogy a kínai kultúrára a hosszú távú orientáció a jellemzó, amit jól példáz az, hogy egy üzleti tárgyalás esetében is legalább akkora súlylyal esik latba a személyes benyomás, mint a konkrét üzleti ajánlat. „A kínaiak, bár nagyon érzékenyek az árra is, csupán a kedvezô árajánlat miatt nem fognak a megbízhatatlannak túnố potenciális üzletféllel megegyezni, hiszen elsődleges céljuk nem az azonnali, gyors megtérülés, hanem a biztos, kellemes, hosszú távú együttmúkködés kialakítása. Éppen ezért, ha sikerül pozitív képet kialakítani magunkról a kínaiak felé, akkor, ha az ár kérdésén meg is bukik az aktuális üzlet, a jövőbeli együttmúködési lehetőségeknél gondolni fognak ránk.” Mivel a munkatársak, alkalmazottak, üzleti partnerek kiválasztásánál sokszor a személyes tényezók dominálnak, ez is azt bizonyítja, hogy a kínaiaknak a hosszú távú együttmúködés, megtérülés fontosabb, mint a rövid távú (Váradi, 2008: 44-45. old.; Juhász, 2014: 75. old.).
Engedékenység - visszafogottság: A visszafogottság leginkább a kelet-európai, a muszlim és az ázsiai országokra jellemzó. Kína a maga 24-es értékével ezen utóbbi csoportba tartozik. A dimenzió alacsonyabb értékeit eléró országokat jellemzi az igazán boldog emberek alacsony száma; egyfajta tehetetlenség érzése (ami akkor következik be, ha nem a saját feladataikkal foglalkoznak); a szólásszabadság nem annyira fontos sem a magánéletben, sem a cégek világában; a szabadidônek nincs akkora jelentôsége, a sport kevésbé népszerú (Hofstede, 2011). A munkahelyeken a szigorúan betartandó szabályok és normák a meghatározóak, ezek között a keretek között kell és lehet érvényesülni a munkavállalóknak. Jackson (1998) szerint is ,,a kínaiak esetében a négy legfontosabb ösztönző tényező közül a szabálykövetés az egyik legfontosabb a másik három mellett: külső jutalmak, internalizált motiváció, belsố motiváció" (Juhász, 2014: 75. old.).

\section{Konklúzió}

A tanulmányban Hofstede kulturális dimenzióinak tükrében kerültek bemutatásra a kínai munkavállalók motiválásának lehetséges alternatívái. Konklúzióként elmondható, hogy az európai ember számára korábban oly távolinak és különlegesnek tartott kínai kultúra elsősorban a globalizáció révén - egyre közelebbivé és egyre inkább megismerhetôvé válik. A globalizáció hatásaként egyre több és több kínai munkavállalóval találkozunk mindennapjaink során, és itt már nem csak a kínai üzletekre és éttermekre kell gondolni, hanem más egyéb szolgáltatásokat nyújtó intézményekre (nyelviskolákra, bankokra, egészségügyi intézményekre). A velük való kommunikáció, kapcsolattartás nem választható külön sajátos munkavállalói kultúrájuktól, életfelfogásuktól, végső soron motivációjuktól és motiválhatóságuktól. Jelen tanulmány „csak” Hofstede dimenzióinak tükrében vizsgálta a kínaiak motiválhatóságát, holott még számos kutató vizsgálataira lehetne hivatkozni, ezek viszont meghaladják a tanulmány kereteit. Egyvalami azonban egészen bizonyos: nekünk, európaiaknak is meg kell ismernünk a kínai munkavállalókat, kultúrájukat, motivációjukat, mert már a közeljövốben szükségünk lehet rá.

\section{Felhasznált irodalom}

Bakacsi Gy. - Takács S. (1998): Honnan - Hová? A nemzetközi és szervezeti kultúra változásai a kilencvenes évek közepének Magyarországán. Vezetéstudomány, XXX. évf. 2. szám: 15-22. o.

Boda Gy. - Virág I. (2010): Ütemvakság. Közgazdasági Szemle, LVII. évf., 2010. december: 1087-1104. o. 
Csath M. (2008): Interkulturális menedzsment - Vezetés eltérô kultúrákban. Budapest: Nemzeti Tankönyvkiadó

Heidrich B. (2006): Intercultural Management. Miskolc: Miskolci Egyetem

Hofstede, G. - Hofstede, G.J. - Minkov, M. (2010): Cultures and Organizations: Software of the Mind. New York: McGraw-Hill

Hofstede, G. (1980): Motivation, Leadership and Organization: Do American Theories Apply Abroad? Organization Dynamics, Summer 80, Vol. 9, Issue 1: p. 42-63.

Hofstede, G. (1983): The cultural relativity of organizational practices and theories. Journal of International Business Studies, Vol. 14, No. 2: p. 75-89.

Hofstede, G. (1984): Culture's Consequences: International differences in work - related values. Beverly Hills, CA: Sage Publications

Hofstede, G. (1996): Cultures and Organizations: Software of the Mind. Maidenhead, UK: McGraw-Hill

Hofstede, G. (2006): What did GLOBE really measure? Researchers minds versus respondents" minds. Journal of International Business Studies, Vol. 37: p. 882-896.

Hofstede, G. (2010a): Geert Hofstede weboldala; http:// www.geert-hofstede.com/, (letöltés: 2010. dec. 15.)

Hofstede, G. (2010b): Geert Hofstede holland weboldala; http://www.geerthofstede.nl, (letöltés: 2010. dec. 15.)

Hofstede, G. (2011): Dimensionalizing Cultures: The Hofstede Model in Context. Online Readings in Psychology and Culture, Unit 2., The Berkeley Electronic Press. http://scholarworks.gvsu.edu/orpc/ vol2/iss1/8, (letöltés: 2013. december 13.)

Hofstede, G. (2012): Geert Hofstede weboldala. http://www. geerthofstede.nl/dimension-data-matrix, (letöltés: 2012. október 16.)

House, R.J. - Hanges, P.J. - Javidan, M. - Dorfman, P.W. - Gupta, V. (2004): Culture, Leadership, and Organizations (The GLOBE Study of 62 Societies). London: Sage Publications

Hunyady Gy. - Székely M. (2003): Gazdaságpszichológia. Budapest: Osiris Kiadó

IMF (2014): World Economic Outlook Database; International Monetary Fund, April, 2014, http:// www.imf.org/external/pubs/ft/weo/2014/01/weodata/ weoselco.aspx?g=2001\&sg=All+countries, (letöltés: 2014. szeptember 3.)

Jackson, T. (1998): Foreign companies and Chinese workers: employee motivation in the People's Republic of China Centre for Cross Cultural Management Research. Oxford: EAP European School of Management, UK and Mette Bak BASF, Shanghai, China Journal of Organizational Change Management, Vol. 11, Issue 4: p. 282-300.

Javidan, M. - House, R.J. - Dorfman, P.W. - Hanges, P.J. de Luque, M.S. (2006): Conceptualizing and measuring cultures and their consequences: a comparative review of GLOBE's and Hofstede's approaches; Journal of
International Business Studies, Vol. 37, Issue 6: p. $897-$ 914.

Juhász I. (2014): Kínai munkavállalók motiválásának vezetői kihívásai - kulturális sajátosságok mint korlátok és mint lehetőségek. Marketing \& Menedzsment, XLVIII. évf., 2. szám: 71-82. o.

King-Metters, K.H. - Metters, R.D. (2013): What they know just ain't so: what multinationals need to know about Chinese workers. Pannon Management Review, Volume 2, Issue 1, March

Klein S. (2007): Vezetés- és szervezetpszichológia; Budapest: Edge 2000 Kiadó

Kopfer-Rácz K. - Hofmeister-Tóth Á. - Sas D. (2013): A hazai kis- és közepes vállalatok szociokulturális beállítódása a Hofstede-dimenziók mentén. Vezetéstudomány, XLIV. évf. 10. szám: 2-11. o.

Lemoine, K. - Jansson, C. (2010): What to do with the Chinese? International Business and Economics Program, China, Bachelor thesis, Kristianstad University. http://www.diva-portal.org/smash/get/diva2:329831 /FULLTEXT01, (letöltés: 2012. október 16.)

Marosi M. (2003): Japán, koreai és kínai menedzsment. Budapest: Aula Kiadó

McSweeney, B. (2002): Hofstede's "Model of Natinal Cultural Differences and Consequences: A Triump of Faith - A Failure of Analysis". Human Relations, Vol. 55, No. 1: p. 89-118.

MFB (2013): A magyar-kínai külkereskedelem alakulása. MFB Periszkóp 2013. április, https://www.mfb.hu/ aktualis/mfb-periszkop/mfb-periszkop-2013-aprilis, (letöltés: 2013. október 28.)

Mikulás G. (2011): Versenyképességi kulturális orientációk azonosítása vezetôi narrációkban. PhD-értekezés. Gödöllő: Szent István Egyetem Gazdálkodás és Szervezéstudományok Doktori Iskola

Poór J. (2009): Nemzetközi emberi eróforrás menedzsment; Budapest: Complex Kiadó Jogi és Üzleti Tartalomszolgáltató Kft.

Primecz H. (1999): Hofstede - más szemmel. Marketing \& Menedzsment, XXXIII. évf., 3-4. szám: 111-115. o.

Primecz H. (2006): Étikus és émikus kultúrakutatások. Vezetéstudomány, XXXVIII. évf., Különszám: 4-15. oldal

Szretykó Gy. (2013): Nemzeti kultúrák, stratégia és a cégvezetés: az amerikai és a kínai HR-stratégiák tükrében. Humánpolitikai Szemle, 3-4. sz.

Thakur, M. (2009): India Cultural Analysis Using Hofstede's Cultural Dimension Analysis and Schein Modelling. Toronto, Ontario: Schulich School of Business - York University

Váradi V. (2008): Kína: az értékek megnyilvánulása Hofstede-dimenzió mentén. EU Working Papers, 11.évf., 3. szám.http://epa.oszk.hu/00000/00026/00040/ pdf/euwp_EPA00026_2008_03_030-047.pdf, (letöltés: 2013. augusztus 29.) 